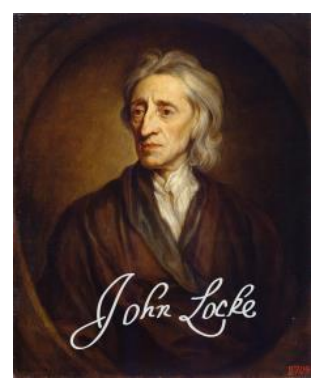

LOCKE STUDIES

Vol. 14

https://doi.org/10.5206/ls.2014.735 | ISSN: 1476-0290

Originally published: 2014

Published online: 19 FEBRUARY 2018

(C) Locke Studies, 2014

\title{
Review of Locke's Metaphysics by Matthew Stuart
}

\author{
VICTOR NUOVO (HARRIS MANCHESTER COLLEGE, OXFORD, AND MIDDLEBURY \\ COLLEGE)
}

Recommended citation:

Nuovo, Victor. "Review of Locke's Metaphysics by Matthew Stuart." Locke Studies 14 (2014): 263-271.

https://doi.org/10.5206/ls.2014.735

For more information about this article:

https://ojs.lib.uwo.ca/index.php/locke/article/view/735

Locke Studies is published by The John Locke Society.

This is an open access article published under the terms of the Creative Commons AttributionNonCommercial-ShareAlike 4.0 International license, which permits use, distribution and reproduction in any medium, provided the original work is properly cited and shared under the original license. 
Matthew Stuart, Locke's Metaphysics. (Oxford: Clarendon Press, 2013. Pp. xvii, 522. Price £55. ISBN: 978-0-19-964511-4.)

\section{Reviewed by VICTOR NUOVO}

This is a substantial book in several ways. To begin with, it is great in bulk and long in content. But it is so well ordered that in spite of its length it can be navigated with ease. Its contents are topically arranged. Its seventy sections numbered consecutively are distributed among ten chapters. Its topics and subtopics are described in a table of contents and elaborated in summaries at the head of each chapter, which provide the reader with a running argument. With these aids, it is possible to survey the entire contents of the book in short order and to jump from one place to another without losing one's way. A table of contents and index locorum complete a perfect set of navigational aids. The method is reminiscent of Locke.

Lastly, getting down to the matter at hand, and with apologies for the pun, this book is substantial in theme, and for just this reason its great length is warranted, for, by approaching Locke as a metaphysical thinker and his Essay as rich and profound in metaphysical insights, Stuart has attempted something unusual and unexpected. Some may think it also quixotic, but I believe that it is timely and important. And, once one gives in to the thought, it becomes obvious and compelling. Consider the theme of the Essay. It is the understanding, which, Locke, wearing a Baconian hat, solemnly informs his readers 'sets man above the rest of sensible Beings, and gives him all the Advantage and Dominion, which he has over them', something that 'even for its Nobleness' is worthy of painstaking study. (Essay, I. i. 1) These remarks are metaphysically dense, although this fact I fear often escapes the notice of even seasoned Locke scholars. The chain of being, to which Locke is alluding, is if anything metaphysical. The exercise that Locke calls upon his readers to try, of making the understanding its own object, a task requiring 'Art and Pains', 
leads to the discovery of something like a spiritual substance, or at least a sort of substance that rivals matter in what we know or don't know about it. Its discovery requires an endeavor comparable to a Platonic turning around. The recovery or rediscovery of the rich philosophical content in places in Locke's Essay, where it has been routinely ignored or dismissed as of no relevance, will make the already rich Essay seem even richer, and this will be a benefit to philosophy. This, I believe, is Stuart's purpose, and I applaud him for it.

Nevertheless, I cannot but wonder why Locke, who was suspicious of formal speculative thinking, should, whilst writing a book on the origin and limits of knowledge and belief, fill it with metaphysical reflections. Stuart's remark, (Preface, vi), that Locke was a 'brilliant polymath' who could not resist pursuing a metaphysical question whenever one came into view, and that the Essay, 'a sprawling, discursive work', mirroring his mind, was an accommodating place to deposit metaphysical thoughts and much else that belong elsewhere, cannot be taken as a satisfactory explanation. It is a caricature of Locke and his book.

I also wonder whether Locke would have labelled the reflections presented by Stuart as metaphysical or as something else. It should be noted that in the division of the sciences outlined in Essay IV.xxi, metaphysics is not even assigned a place. It is replaced by Physics, 'The Knowledge of Things, as they are in their own proper Beings, their Constitutions, Properties, and Operations, whereby I mean not only Matter, and Body, but Spirits also'. The remaining two divisions are

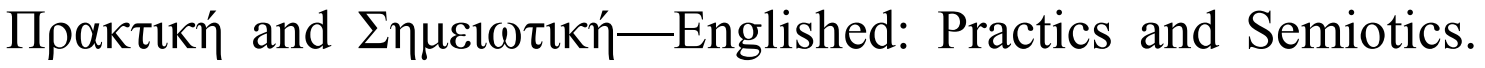
They concern, respectively, the art of rightly using our active powers to achieve good and useful things, and the nature of the signs that the mind employs 'for the understanding of things, or conveying knowledge to others'. Although I am not sure of this, I have the strong suspicion that Locke was being deliberately innovative in these names. 'Semiotics', in the seventeenth century was a term used in medicine for interpreting symptoms, as Locke, 
a virtuoso physician and sometime collaborator with Thomas Sydenham, well knew. It is to this last division that the Essay belongs. Locke's Essay is a logic of human enquiry and of right discourse tentatively executed-hence its title. That the Essay sprawls, which is to say, overflows its disciplinary boundaries to accommodate metaphysical, or rather physical or natural philosophical, and moral problems seems a natural consequence of its purpose. Locke was trying out his work as he wrote it, testing its capacity to discover truth. In the light of all of this, Stuart might better have entitled his book 'Locke's Physics', or better 'Locke's Enlarged Physics', for it should be clear from reading the Essay that if Locke reduced metaphysics to physics, he also enlarged it to accommodate God and finite spirits, immaterial things, and relied on divine power to explain the properties of things and our perception of them.

Thus, although, like Stuart and most other contemporary Anglophone philosophers, I am inclined to regard the themes treated in his book as metaphysical: substance, essence, identity, mind and matter, free agency, and the rest, and am disposed to call them such, and will do so in this review, Locke's removal of metaphysics from the sciences must give us pause-all the more so if one's purpose in reading Locke, or any other dead philosopher, is to enliven contemporary philosophy by recovering or retrieving philosophical insights of great moment that may have been lost or become unfashionable.

Moreover, I wonder whether Stuart's method, which is to approach his subject from the standpoint of concepts and methods of contemporary analytical philosophy, may cause him to overlook important aspects of Locke's philosophy; or whether, as something that goes along with this, by charging him peremptorily with philosophical errors-inconsistencies, careless errors, fallacies, or instances of conceptual vagueness-without first considering their origin and context, he occasionally misleads. Here are some instances, where I believe this happens. 
Ideas and Qualities: A somewhat notorious error or type of error is Locke's practice of conflating ideas and their objects, modes and ideas of modes, and ideas and qualities. Locke's readiness to apologize for these practices may seem an admission of guilt. But to take it as such would be a mistake, for his apologies on occasions are invariably not admissions of guilt but claims for originality. ${ }^{1}$

An instance of this occurs in Essay II.viii.8.

Thus a Snow-ball having the power to produce those Ideas in us of White, Cold, and Round, the Powers to produce those Ideas in us, as they are in the Snow-ball, I call Qualities; and as they are Sensations, or Perceptions, in our Understandings, I call them Ideas: which Ideas, if I speak of sometimes, as in the things themselves, I would be understood to mean those Qualities in the Objects which produce them in us.

Here Locke offers a reason for his dual use of 'Ideas'. 'Idea' and 'quality' denote manifestations of the very same productive power. Jonathan Bennett has given this a name: substantive conflation, which, in Locke and other serious philosophers, he regards as an unavoidable philosophical pathos. ${ }^{2}$ Stuart regards it without sympathy as a mere muddle, always annoying, and in some cases the source of serious misunderstanding (3). But it is neither.

Locke offers two explanations for his practice of conflation. One is psychological, the other, physiological. The former is given in Draft A.

When I speak of simple Ideas as existing in things I would be understood to mean such a constitution of that thing which produces that Idea in our mindes. Soe that Idea when it is spoken of as being in our understanding is

${ }^{1}$ See John Locke, An Essay concerning Human Understanding ed. P. H. Nidditch (Oxford, 1975), II.xii.4, 165, on modes; also OED, 'mode' I.6b.

2 The expression 'substantive conflation' was coined by Jonathan Bennett, 'Ideas and Qualities in Locke's "Essay", History of Philosophy Quarterly 13 (1996): 73-88. 
the very perception or thought we have there, when it is spoken of as being without is the cause of that perception. \& is supposed to be resembled by it. $^{3}$

There is a tendency to suppose that perceived objects, because they are taken to be the causes of our perception of them, resemble the very ideas we have of them; it is a common human tendency. Thus, it is natural, common, ordinary to suppose that White, Round, and Cold that we take to be in a snowball one holds in one's hand are the same as the ideas of White, Round, and Cold, which on that occasion are present to mind. In this comment, Locke also hints at a physiological or natural philosophical explanation, which is spelled out in Essay, II. viii. 11-13. It is an elaboration of the reason stated briefly above. Bodies produce ideas in us by impulses from the motion of outflows or effluvia, 'singly imperceptible Bodies', whose motion 'must thence be continued by our Nerves, or animal Spirits...to the Brains or seat of Sensation, there to produce in our Minds the particular Ideas we have of them.' There is, then, a continuity of the power of the perceived object from the object itself to the understanding. Locke's explanation has a metaphysical import: it tends towards materialism but swerves toward theism. Thus, he conjectures that although, in the case of secondary qualities, there is no similitude between particles of various size, shape, and motion, and the ideas that enter the mind through their motions, for example, of color or scent in a flower, it is 'not impossible' that God has joined them together. Indeed, this marriage of ideas and physical states becomes in Locke's scheme of things, a regular feature of our experience of the world.

Substance: Stuart believes that Locke's idea of substance is also a muddle, but in this case he is sympathetic with his subject

\footnotetext{
${ }^{3}$ John Locke, Drafts for the Essay Concerning Human Understanding, and Other Philosophical Writings, vol. 1, ed. P. H. Nidditch and G. A. J. Rogers (Oxford, 1990), 82.
} 
(200). He perceives a philosophical pathos in Locke's muddling. On Stuart's account, Locke was aware that he was in a muddle with respect to the idea of substance but was unable to do anything philosophical to escape it. Locke recognized that substance did not fit nicely into his theory of ideas. It is neither an idea of sensation nor one of reflection, hence not a simple idea. It is not a complex idea, for the class of complex ideas of substance includes in itself an idea of substance that originates elsewhere. He seemed at a loss to explain how it came to enter the mind. He does offer an explanation, but it is only a start. In Essay, I. iv. 18, he allows that an idea of substance originates in the mind. It is supposed. So it might be classified as an idea of reflection. However, it is not simple but bare. It is supposed that there must be something upon or in which all these ideas rest or inhere; substance, then, is just a supposed 'under-propping' (Essay, II.xiii.20). 'Under-propping' is an analogy, not anything directly perceived. And because we do not directly perceive what we call substance, it cannot be a determinate idea, as are all simple ideas, nor a determined idea, which is made up wholly of them.

Locke's difficulties increase, according to Stuart, because he entertained two theoretically different ideas of substance. Substance $^{1}$ is the idea of substratum just noted; Substance ${ }^{2}$ is an abstract idea signifying things that subsist in themselves, as distinct from accidents or modes, which inhere or stick to them. Substance $^{1}$ and Substance ${ }^{2}$ represent two very different ways of thinking about substance. Substance ${ }^{2}$ is just the traditional idea of substance entertained in the schools, but there is no evidence that Locke gave any credibility to it. It was an idea to be tolerated. The consequence of Locke's supposed muddle is that the idea of substance, in one or other of its varieties, cannot do any real philosophical work for him. They offer no help in deciding whether space is a substance, or, because the idea of substance is neither a determinate nor determined idea, whether God, finite spirits, and bodies - the three classes of being that Locke admits in his ontology — can be unequivocally termed substances. And 
because the ideas of spirit and matter are fundamentally empty, so are the expressions spiritual substance and material substance. (Essay, II. xiii. 17-20). It should be noted here that Stuart finds a third idea of substance, via. Stuff, which also goes begging.

Locke goes no further than this. Is this a fault or a muddle? It is neither, unless one desires to make him out to be a classical metaphysician - someone who continues the tradition of Aristotle and the Scholastics. I suspect that this may be an underlying intent here. But it was not Locke's intent. The muddle, such as it is, arises from Locke's strict adherence to an empirical method and from the physiological frame within which the Essay was first conceived. The idea of an unseen material ground of all things is central to the Democritean-Epicurean physics that was adopted as a preferred hypothesis by experimental natural philosophers, Locke among them, who flourished in England during the seventeenth century. It served them in lieu of metaphysics and it posited a single kind of particulate stuff constitutive of everything: gods, worlds, gold, water, and persons. The nature of this substance was to be teased out experimentally. (An outcome that Locke doubted would ever be reached).

God and Physics: In chapter 6 of his book, Stuart treats two themes that are central to Locke's metaphysical or physical outlook: the immateriality of God and the origin of properties. Locke connects them in a way that upon reflection reveals a systematic cosmology or universal system of nature divinely fashioned, which I will outline briefly before long.

Stuart claims, on the basis of the proof of divine existence offered in Essay IV. x, that Locke is a substance dualist, for one of Locke's collateral aims was to prove that God is immaterial, whilst accepting that there are material bodies. This is correct, but short sighted, for two reasons: one is Locke's substance scepticism, the other, that Locke entertained the thought and may even have come to believe that there is no real difference between spirit and matter. Suffice it to say, substance dualism was not one of Locke's settled opinions and there is good evidence he finally 
settled on something else. Stuart also avers that Locke was a property dualist, which he relied on to prove divine existence and immateriality. And Locke does indeed argue that certain properties of material bodies - mobility, agency, and thoughtcannot be explained by the operations of matter, and require the existence of an omnipotent wise being to account for them.

It needs to be observed that Locke's proof of divine existence and immateriality was designed to refute materialism. He seizes the materialist maxim, that nothing can be created from nothing, and uses it to prove the divine creation of the world, and then, having accomplished his purpose, triumphantly casts it down and tramples on it, replacing it with the theological doctrine of creatio ex nihilo (Essay, IV. x. 15 and passim). In refuting materialism, Locke's purpose was not to remove matter from being, nor to juxtapose an immaterial substance to it in the realm of being. He imagined something more singular and dynamic.

The system of nature that emerges from all of this is as follows. Beginning at the beginning, the omnipotent God, of whose existence we can be certain, created matter out of nothing and endowed it with the primary qualities of size, shape, and solidity. Then, perceiving that, without mobility, all matter would be a mere lump and unproductive, God added mobility to it, or rather superadded it, for it is inconceivable that matter, given its original essence, could originate motion within itself. And so one may ascend from mere mobility in matter to life, sensation, thought, and free agency. Each step upwards is accomplished by an act of divine creation out of nothing or superaddition, which becomes part of a dynamic system of nature. This system of nature might be described as a sort of emergent materialism, except that, to Locke's mind, these emergent properties in things are not the work of nature but of divine creation. Indeed, Locke carried this further. His notebook 'Adversaria Theologica' includes a long reflection on 1 Cor. 15 on the nature of the spiritual body, incorruptible and immortal, which, St. Paul promises, the elect will be raised to. Locke observes that St. 
Paul's notion of immortality is not the common one. He concludes: 'Soe that immortality is not at all oweing nor built on immateriality as in its own nature incorruptible. The Apostle knew not that argument...but quite the contrary says this corruptible must be changed \& put on incorruption $\&$ this mortal put on immortality' (MS Locke c. 43, 32; John Locke: Writings on Religion ed. Victor Nuovo (Oxford, 2002), 29) It was not long after this that Locke embraced mortalism. All this suggests that Locke came to be a substance monist, but of a sort not commonly imagined by philosophers. If brought to his attention, he might have offered an apology.

Conclusion: These remarks are intended only to show the need for a richer historical context when reading Locke's Essay than Stuart has employed, but, all things considered, this is a very valuable and useful book, from which I have learned much and I recommend it to others without hesitation. When reading Locke's Essay one cannot have too many aids and Stuart's book, I am sure, will stand the test of time and take its place beside the writings of Aaron, Ayers, Bennett, Gibson, and Yolton.

Harris Manchester College, Oxford, and Middlebury College 